\title{
PENGEMBANGAN MEDIA HEALTHY DENTAL BOX (HDB) UNTUK MEMFASILITASI KETERAMPILAN MENGGOSOK GIGI ANAK USIA 4-5 TAHUN
}

\author{
Irna Najiah ${ }^{1}$, Lutfi Nur ${ }^{2}$, Taopik Rahman ${ }^{3}$. \\ ${ }^{1}$ Program Studi PGPAUD UPI Kampus Tasikmalaya \\ ${ }^{2}$ Program Studi PGSD UPI Kampus Tasikmalaya \\ ${ }^{3}$ Program Studi PGPAUD UPI Kampus Tasikmalaya \\ Email : irnanajiah@gmail.com
}

(Received: Mei 2020; Accepted: Mei 2020; Published: Juni 2020)

\begin{abstract}
This research is based on the results of preliminary studies that have been conducted by researchers regarding the importance of brushing teeth. Brushing teeth in children aged 4-5 years is not explained in detail in the curriculum and has an impact on the difficulties faced by teachers in selecting and designing learning media to brush their teeth, therefore researchers design learning media with approaches that are appropriate to the conditions of children in the field. Researchers developed the tooth puppet media into a Healthy Dental Box (HDB) medium to facilitate the brushing skills of children aged 4-5 years. The method used in this research is Design Based Research (DBR) developed by Reeves to design, develop, and test the feasibility of a product to overcome problems in learning. Data collection is done by observation, interview and validation of media experts. In general, the product is declared suitable for use as a learning medium regarding brushing teeth based on the results of media validation by experts in the health sector, experts in the field of learning media and pedagogical experts. Reflections on product development, namely producing Healthy Dental Box (HDB) media to facilitate tooth brushing skills in children aged 4-5 years.
\end{abstract}

Keywords: Learning Media, Healthy Dental Box (HDB), brushing teeth.

\begin{abstract}
Abstrak
Penelitian ini didasarkan pada hasil studi pendahuluan yang telah dilakukan oleh peneliti mengenai pentingnya menggosok gigi. Menggosok gigi pada anak usia 4-5 tahun tidak dijelaskan secara rinci dalam kurikulum dan berdampak pada kesulitan yang dihadapi guru dalam memilih dan merancang media pembelajaran menggosok gigi anak, untuk itu peneliti merancang media pembelajaran dengan pendekatan yang sesuai dengan kondisi anak di lapangan. Peneliti mengembangkan media boneka gigi menjadi media Healthy Dental Box (HDB) untuk memfasilitasi keterampilan menggosok gigi anak usia 4-5 tahun. Metode yang digunakan dalam penelitian ini adalah Design Based Research (DBR) yang dikembangkan oleh Reeves untuk merancang, mengembangkan, dan menguji kelayakan suatu produk untuk mengatasi masalah dalam pembelajaran. Pengumpulan data dilakukan dengan observasi, wawancara dan validasi ahli media. Secara umum produk dinyatakan layak digunakan sebagai media pembelajaran mengenai menggosok gigi berdasarkan hasil validasi media oleh ahli dalam bidang kesehatan, ahli bidang media pembelajaran dan ahli pedagogik. Refleksi dari pengembangan produk, yaitu menghasilkan media Healthy Dental Box (HDB) untuk memfasilitasi keterampilan menggosok gigi pada anak usia 4-5 tahun.
\end{abstract}

Kata Kunci : Media Pembelajaran, Healthy Dental Box (HDB), Menggosok gigi. 


\section{PENDAHULUAN}

WHO "Health is a state of complete physical and sosial well beng and not merely the absence of diseace and infirmity". Sedangkan menurut UU No. 36 tahun 2009 yang berbunyi "Kesehatan adalah keadaan sehat, baik secara fisik, spiritual maupun sosial yang memungkinkan setiap orang untuk hidup prodiktif secara sosial dan ekonomis". Sedangkan menurut WHO "Health is a state of complete physical and sosial well beng and not merely the absence of diseace and infirmity". Salah satu bentuk kesehatan yang harus dijaga yaitu kesehatan gigi dan mulut dengan melakukan kegiatan menggosok gigi.

Menggosok gigi yang baik dan benar menjadikan gigi sehat. Namun jika menggosok gigi belum tepat maka mengakibatkan gigi tidak sehat. Gigi yang tidak sehat menyebabkan bau mulut yang mengganggu dalam berkomunikasi. Oleh sebab itu, penting bagi anak untuk merawat gigi sejak dini dengan menggosok gigi agar gigi tetap sehat dan mulut tidak sehat dantidak berbau.

Pelatihan menggosok gigi pada anak usia dini perlu dipelajari. Sujiono (2012) mengungkapkan "anak usia dini adalah sosok individu yang sedang menjalani proses perkembangan yang pesat dan fundamental bagi kehidupan selanjutnya". Anak usia dini sedang berada pada periode emas dalam segala aspek perkembangan manusia dimana kognisi fisik, emosional dan sosial pada periode ini meningkat sebesar 50\%. Sedangkan menurut Ngatemi (2020) Anak usia dini adalah waktu yang ideal untuk mengembangkan keterampilan motoric termasuk menyikat gigi sehingga menimbulkan rasa tanggung jawab atas keberishan dirinya sendiri. Menggosok gigi pada anak usia dini dapat mengembangkan fisik motoriknya dari cara memegang sikat, menuangkan pasta gigi kebulu sikat, memegang gayung, mengambil air dari bak, berkumur, menyikat gigi bagian demi bagian, membersihkan alat gigi sampai ia menyimpan kembali perlengkapan menggosok gigi ketempat semula. Namun fakta yang ditemukan dilapangan masih banyak anak yang menggosok gigi hanya bagian tertentu saja bahkan tidak mengikuti tahapan dengan benar, sehingga hasil yang didapat seringkali kurang bersih sehingga dapat menimbulkan penyakit gigi.

Rahardjo (2014) mengungkapkan "karies gigi merupakan salah satu hal yang paling umum penyakit menular di Indonesia". Bahkan Lokhandwala (2020) menyebutkan karies gigi adalah salahsatu penyakit menular di Dunia prevalasi karies ada dimana-mana disebagian besar negara berkembang selama bertahuntahun, meski prevalensi keparahannya menurun, namun populasi yang signifikan tetap pada resiko karies tinggi. Karies gigi ini juga sering ditemkan pada anak usia dini. Laporan terbaru mengenai kesehatan gigi dan mulut di Iran menunjukan prevalasi tinggi karies pada anak-anak prasekolah, lebih dari $87 \%$ anak usia 5-6 tahun dengan dmft rata-rata 5,16 dan komponen terdiri lebih dari 70\% dari total mean. Di Indonesia sendiri ditemukan " $23,4 \%$ penduduk Indonesia mengalami permasalahan gigi dan mulut sekitar 1,6\% mengalami kehilangan seluruh gigi asli" Zulkifli (2020). Dilihat dari angka diatas membuktikan bahwa masih rendahnya kesadaran masyarakat mengenai pentingnya kesehatan gigi dan mulut.

Menurut hasil observasi dan wawancara disalah satu TK di Cipedes Kota Tasikmlaya sebagian besar anak masih rendah kesadarannya mengenai menggosok gigi bahkan anak-anak sulit sekali menggosok gigi. Anak-anak disana masih kurang trampil dalam menggunakan jari-jemari tangannya untuk melakukan kegiatan menggosok gigi. Maka dari itu penting kiranya menggosok gigi yang baik dan benar dipelajari anak sedini mungkin.

Menggosok gigi yang baik dan benar sesuai yang diungkapkan oleh Erwana (2013) mengungkapkan "cara menggosok gigi yang benar melalui empat tepat lima sempurna maksudnya 4T tepat alat, tepat cara, tepat waktu, tepat target dan 5 sempurna. Salah satu cara memberikan pengetahuan sedini mungkin mengenai cara menyikat gigi yang benar salah satunya melalui media pembelajaran. Menurut 
Santyasa (2007) mengungkapkan "media pembelajaran adalah segala sesuatu yang dapat menyalurkan pesan sehingga dapat menstimulus perhatian, minat, pikiran dan perasaan sisiwa dalam kegiatan belajar sehingga mencapai tujuan pembelajaran yang maksimal. Media pembelajaran mengenai menggosok gigi masih terbatas dan kurang efektif. Keterbatasan media pembelajaran membuat anak kesulitan untuk memahami, mempraktekan menggosok gigi.

Dalam penelitian ini peneliti menggunakan media sebagai alat bantu agar anak mampu dan trampil dalam melakukan kegiatan menggosok gigi. Peneliti memberi nama media tersebut media Healthy Dental Box (HDB) yang diadopsi dari media boneka gigi. Media ini berbentuk box yang dilengkapi dengan boneka gigi yang menyerupai phantom gigi. Media ini diharapkan dapat membuat anak lebih trampil dalam menggosok gigi.

Berdasarkan dari permasalahan tersebut, peneliti tertarik untuk mengembangkan media pembelajaran berbasis pengembangan dengan metode Design Based Research yang berjudul "Pengembangan Media Healthy Dental Box (HDB) untuk Memfasilitasi Keterampilan Menggosok Gigi Anak Usia 4-5 Tahun".

\section{TINJAUAN PUSTAKA}

Kemendikbud no 137 tahun 2014 tentang standar nasional pendidikan anak usia dini bahwa perkembangan fisik motorik terbagi menjadi tiga bagian yaitu; fisik motorik kasar, fisik motorik halus dan kesehatan dan perilaku keselamatan.

Fisik motorik kasar merupakan gerakangerakan tubuh yang menggunakan otot-otot besar. Contohnya melompat, menendang, berlari dan lain-lain. Yasbiati (2017) mengemukakan bahwa "motorik halus merupakan suatu gerakan yang hanya melibatkan otot-otot kecil, seperti jari jemari dan gerakan pergelangan tangan dengan cepat dan tepat". Gerakan motorik halus memerlukan koordinasi mata dan tangan yang baik..

Pembelajaran mengenai kesehatan dan perilaku keselamatan memiliki peranan penting. UU No. 23 tahun 1992 (dalam Ryadi, S.L.A, 2018, hlm 2) berbunyi "Kesehatan adalah keadaan sejahtera dari badan, jiwa dan sosial yang memungkinkan setiap orang hidup produktif secara soisal dan ekonomis".

Menurut Ryadi (2018) "Kesehatan adalah keadaan sehat, baik secara fisik, spiritual maupun sosial yang memungkinkan setiap orang untuk hidup prodiktif secara sosial dan ekonomis". Sedangkan menurut WHO "Health is a state of complete physical and sosial well beng and not merely the absence of diseace and infirmity".

Jadi dapat ditarik kesimpulan kesehatan adalah keadaan sehat jasmani maupun rohani yang memungkinkan setiap orang untuk hidup prodiktif secara sosial dan ekonomis. Untuk itu kesehatan sangat penting sekali begitupun kesehatan pada anak. Kesehatan pada anak harus diperhatikan dengan baik.

Ryadi (2018) mengemukakan "Prilaku kesehatan seseorang biasanya memiliki kecenderungan dipengaruhi kepercayaan". Pada tahun 2020 digemparkan dengan mewabahnya virus corona atau COVID-19 yang ditemukan pada tahun 2019 dan mewabah hingga pandemi pada tahun 2020 . Resiko biologis penularan inhalasi covid-19 sangat tinggi ketika melakukan prosedur gigi karena penggunaan handpieces dibawah irigasi, yang mendukung difusi partikel aerosol dari air liur, darah dan sekresi. Izzetti (2020). Untuk membatasi penularan virus corona lebih baik perawatan gigi dilakukan di rumah dengan cara menggosok gigi. Peran orang tua dan guru sangat dibutuhkan upaya yang dapat dilakukan salah satunya mengenai kebersihan gigi dan mulut.

Mumpuni (2013) menyatakan bahwa "Gigi merupakan tulang keras dan kecil-kecil berwarna putih yang tumbuh tersusun, berakar dalam gusi dan berfungsi untuk mengunyah juga menggigit". Gigi merupakan bagian dari mulut. Selain gigi didalam mulut terdapat lidah dan ludah. Lidah (lingua) adalah kumpulan otot rangka pada bagian lantai mulut yang membantu pencernaan makanan. Ludah adalah 
air yang keluar dari mulut yang dihasilkan oleh kelenjar ludah.

Semua bagian tubuh manusia memiliki tugas, peran dan fungsinya masing-masing termasuk gigi. Berikut fungsi gigi menurut Hidayat (2016), yaitu; gigi sebagai pengunyah yaitu gigi berperan penting dalam menghaluskan makanan agar mudah ditelan dan dicerna, gigi juga berfungsi untuk mengeluarkan dan melafalkan bunyi ataupun huruf-huruf tertentu, seperti huruf T, V, F, D dan S. tanpa gigi bunyi huruf-huruf tersebut tidak akan terdengar sempurna atau jelas. Sehingga berbicarapun akan terdengar kurang atau bahkan tidak sempurna. Fungsi gigi yang ketiga selain gigi berfungsi sebagai pengunyah dan berbicara, gigi juga berfungsi sebagai estetik. Tanpa adanya gigi sebuah senyum tidak akan lengkap tanpa deretan gigi yang bersih dan rapi. Gigi juga sebagai penjaga kesehatan rongga mulut dan rahang, banyak hal yang akan terjadi jika gigi kita hilang, diantaranya gangguan pengunyahan makanan, terutama pada susunan gigi yang tidak teratur (maloklusi). Tulang alveolar yang berkurang (resorpsi).

Menggosok gigi adalah metode kontrol plak yang paling umum, mudah dan efektif. Giri, (2018) menyatakan bahwa "pada saat yang sama menyikat gigi dengan teknik yang tepat mengurangi plak secara efektif dan menjaga integritas gigi juga perinonsium disekitarnya". Gigi dan mulut merupakan bagian tubuh yang langsung bersinggungan dengan makanan dan minuman yang masuk ke dalam tubuh, rongga mulut termasuk gigi dan lidah rentan terserang penyakit.

Gigi yang tidak sehat dan menyebabkan bau mulut akan mengganggu dalam berkomunikasi khususnya dalam hal berbicara. Oleh sebab itu, penting bagi anak untuk merawat gigi sejak dini dengan menggosok gigi agar gigi tetap sehat dan tidak mengeluarkan bau busuk.

Keberhasilan pemeliharaan kesehatan gigi dan mulut juga dipengaruhi oleh faktor penggunaan alat, metode penyikatan gigi, lamanya menyikat gigi serta frekuensi dan waktu penyikatan yang tepat.
Pada umumnya anak usia dini masih tidak tepat dalam menggosok gigi maka dari itu penyakit karies gigi lebih banyak ditemukan pada anak dibanding orang dewasa, oleh karena itu orang tua maupun guru sangat diharapkan terjun dan memberikan arahan kepada anak mengenai menggosok gigi yang baik dan benar.

Tingginya angka penyakit gigi dan mulut saat ini dipengaruhi oleh berbagai faktor. Razi (2018) mengungkapkan bahwa "salah satu faktor tersebut adalah rendahnya kesadaran masyarakat mengenai kebersihan gigi dan mulut". Zulkifli (2020) mengungkapkan ditemukan $23,4 \%$ penduduk Indonesia mengalami permasalahan gigi dan mulut dan sekitar 1,6\% mengalami kehilangan seluruh gigi asli. Bukan hanya di Indonesia laporan terbaru mengenai kesehatan mulut di Iran menunjukan prevalensi tinggi karies pada anak-anak prasekolah lebih dari $87 \%$ anak usia 5-6 tahun dengan dmft rata-rata 5,16 dan komponen terdiri lebih dari $70 \%$ dari total mean. Razeghi, (2020). Dilihat dari angka ini membuktikan bahwa masih rendahnya kesadaran masyarakat mengenai kesehatan gigi dan mulutnya.

Tidak sedikit masyarakat menghiraukan kesehatan gigi dan mulut dan juga tidak sedikit masyarakat yang sudah terkena penyakit gigi ia baru menyadari perilaku tidak sehat dan menganggap angin lalu terhadap pencegahan penyakit gigi dengan cara paling sederhana yaitu menggosok gigi dengan baik dan benar. Faktor perilaku masyarakat inilah yang menjadi permasalahan yang akhirnya berdampak kepada perilaku anak dalam menggosok gigi. Hal ini dibuktikan dengan survei Riskesdas (2013) yang menyatakan bahwa '98,3\% penduduk Indonesia sudah menyikat gigi tiap hari, namun hanya $2,3 \%$ yang menyikat gigi dengan benar. Hal ini menjadi masalah, karena salah satu cara pencegahan yang efektif terhadap terjadinya penyakit karies yaitu melalui tindakan menyikat gigi. Walaupun tidak menimbulkan kematian, namun kerusakan gigi yang ditimbulkan dapat menurunkan tingkat 
produktivitas seseorang karena dapat menyebabkan rasa sakit yang mengganggu'.

Mengkonsumsi makanan yang terlalu banyak mengandung gula dan soda juga merupakan salah satu faktor yang bisa mempengaruhi kesehatan gigi. Anak usia dini identik menyukai berbagai maknan yang manis-manis seperti permen dan lain-lain, dalam kedokteran gigi, bahan ini disebut bahan kariogenik yang berpotensi menyebabkan karies. Sebaiknya beri anak makanan yang diolah sendiri oleh orang tua dari bahan-bahan alami, seperti buah-buahan, sayur-sayuran. "Buah dan sayuran telah terbukti secara klinis, baik untuk kesehatan gigi. Buah dan sayuran mengandung bahan vitamin dan mineral yang dapat menguatkan gigi" (Erwana 2013). Agar gigi tetap kuat berikut tips mencegah gigi keropos menurut Chomaria (2015) mengungkapkan:

"Batasi konsumsi gula pada anak, seperti permen, cokelat, es krim. dan softdrink (minuman bersoda), Lakukan perawatan gigi secara teratur, seperti menyikat gigi yang tepat dua kali sehari dan flossing (membersihkan gigi dengan benang) setiap hari dan gunakan pasta gigi yang mengandung flouride, penggunaan flouride secara teratur dapat memerangi pengeroposan gigi".

Penyakit yang bisa saja amuncul pada anak usia dini salah satunya karies gigi. Karies gigi pada anak prasekolah menimbulkan resiko yang jelas terhadap kesehatan umum sebagai penyakit umum pada anak-anak, selain itu penyakit ini dikaitkan dengan dampak fungsional, estetika dan psikologiis yang nyata pada kualitas hidup anak keluarga dan membebani biaya yang tinggi. Razeghi (2020). Chomaria (2015) mengungkapkan "Lubang gigi disebut juga karies gigi disebabkan karena infeksi bakteri. Jika tidak dirawat, lubang gigi akan semakin besar dan dalam hingga akhirnya terjadi infeksi yang dapat mencapai sarafan gigi”. Jika terdapat gigi berlubang lama kelamaan gigi tersebut akan mati jika tida segera diatasi. Jika terjadi pada anak usia dini anak akan mengalami kesulitan mengunyah makanan. Apabila kejadian ini berlanjut, bisa berujung pada penurunan nafsu makan dan dalam jangka panjang anak dapat mengalami kurang gizi. Infeksi gigi yang berlanjut ke jaringan lunak dapat menyebabkan terjadinya abses (seperti bisul berisi nanah). Erwana (2013) mengungkapkan bahwa "4 tanda kesalahan cara menyikat gigi akan berakibat timbulnya karang gigi, radang gusi, gigi sensitive, dan nafas berbau". Berikut penjelasannya:

1. Karang gigi

Karang gigi adalah plak yang mengeras karena proses mineralisasi. Kalau karang ini muncul maka bisa dipastikan tidak menyikat gigi dengan efektif dan tepat guna sehingga tidak sampai menghilangkan plak yang ada. Menurut Nardi (2016) mengungkapkan "tes kolorimetri menggunakan agen pengungkap plak, seperti erythrosine, secara bertahap telah diintegrasikan kedalam protocol umum yang bertujuan untuk memverifikasi penggunaan teknik menyikat gigi harus dengan benar".

2. Radang Gusi

Radang gusi memiliki gambaran atau tanda-tanda berwarna merah tua terlihat bengkak, terasa sakit, dan mengeluarkan darah baik secara tiba-tiba ataupun karena terkena kontak dengan sesuatu seperti sikat gigi, ditekan, makanan dan sebagainya. Hal ini disebabkan kerena menyikat gigi dengan tekanan yang terlalu besar pada gusi. Bisa juga karena plak yang ada didaerah perbatasan gusi dan gigi tidak dibersihkan dengan cukup baik.

3. Gigi Sensitif

Sesungguhnya tidak ada penyakit gigi sensitif, namun istilah ini digunakan untuk menggambarkan rasa ngilu yang muncul pada gigi saat kontak dengan suhu yang terlalu dingin atau panas. Hal ini dapat diakibatkan karena menikat email gigi terlalu keras.

4. Napas Bau

Napas bau atau bau napas lebih diakibatkan oleh kegagalan pembersihan mulut secara keseluruhan, membersihkan mulut bukan berarti menyikat giginya saja. Meski demikian pembersihan/ penyikatan mahkota gigi yang tidak tepat juga dapat menimbulkan bau mulut. 
Sisa makanan yang terjebak disela sel agigi dan lubang gigi dapat menyebabkan napas bau.

Lakshmi (2018) mengemukakan teknik atau cara menyikat gigi biasanya terdiri dari horizontal, vertical dan dengan gerakan memutar. Melakukan gosok gigi secara horizontal dapat menghilangkan plak dari permukaan luar dan dalam yang halus, namun penggosokan yang kuat akan mengakibatkan resesi gingiva juga pasta gigi yang kasar dan sikat gigi yang keras berstektur akan mengakibatkan area abrasi gigi. Selain teknik menyikat gigi harus benar dan tepat, pemberian pasta gigi juga harus diperhatikan agar sesuai dengan kebutuhan si anak. Seperti yang dikemukakan oleh Hidayat (2016) mengemukakan "Pemberian pasta gigi pada balita tidak dianjurkan, menyikat gigi pada balita sebaiknya tidak menggunakan pasta gigi. Sedangkan untuk anak usia 3 tahu keatas sebaiknya berikan pasta gigi kira-kira $0,5 \mathrm{~cm}$ atau sebesar biji kacang polong". Bukan hanya teknik dan penyesuaian pasta gigi yang diberikan namun banyak hal lain yang harus diperhatikan ketika menggosok gigi.

drg. Agam Ferry Erwana (2013) mengungkapkan cara menyikat gigi yang Benar melalui 4 Tepat 5 Sempurna. 4 tepat (tepat alat, tepat cara, tepat waktu, tepat target) dan 5 sempurna.

1. Tepat Alat

Tepat Alat yang dimaksud adalah harus benar dalam memilih alat yang digunakan untuk membersihkan gigi, yaitu sikat gigi. Baruah (2017) mengemukakan 'sikat gigi manual rata-rata bertahan hanya 3 bulan, lebih baik lebih sering mengganti sikat gigi. Perkiraan 3 bulan ini bisa bervariasi tergantung kebiasaan menyikat'. Disarankan memiliki sikat gigi lebih dari satu dan digunakan berselingan memastikan pengeringan diantara sikat. Erwana (2013) mengungkapkan berikut kriteria sikat gigi yang baik:

a. Gagang sikat harus lurus, agar memudahkan mengontrol gerakan penyikatan.

b. Kepala sikat tidak lebar dan membulat, agar tidak melukai jaringan lunak lain seperti pipi, saat menyikat gigi bagian belakang.

c. Bulu sikat dipilih yang lembut agar tidak melukai gusi dan mudah masuk ke selasela gigi.

2. Tepat Cara

Gerakan menyikat gigi yang tepat:

a. Gerakan untuk bagian luar gigi depan adalah keatas kebawah jangan digosok dengan gerakan menyamping bolak-balik karena bisa menyebabkan gusi menjadi rusak;

b. Bagian luar gigi belakang jangan digosok dengan gerakan naik turun, tetapi dengan gerakan maju mundur atau memutar. Gerakan naik turun kurang efektif untuk membersihkan gigi belakang bagian luar.

3. Tepat Waktu

Hidayat, R (2016) menyatakan bahwa "waktu terbaik untuk menggosok gigi adalah setelah makan dan sebelum tidur". Menyikat gigi setelah makan bertujuan mengangkat sisasisa makanan yang tertinggal didalam mulut termasuk pada sela-sela gigi dan gusi. Sedangkan menggoosok gigi sebelum tidur bertujuan untuk menahan perkembangan bakteri dalam mulut karena keadaan mulut saat tidur tidak diproduksi ludah yang berfungsi membersihkan gigi dan mulut secara alami.

4. Tepat Target

Meliputi tepat membersikan daerah yang perlu dibersihkan. Gigi bukan Cuma bagian depan dan bagian luar saja. Gigi juga ada bagian belakang dan dalam. Bagian-bagian ini terkadang terlewat atau sengaja tidak dibersihkan.

\section{Lima Sempurna}

Setelah 4 tepat saatnya lima sempurna. Gunakan alat bantu daerah gigi dan mulut yang perlu dibersihkan adalah gigi, pipi, lidah dan langit-langit. Jadi selain sikat gigi, bisa menggunakan alat bantu, jika memerlukan alat bantu pilihan yang bisa digunakan adalah pembersih lidah, obat kumur dan dental floss (benang gigi).

Mengingat pentingnya menggosok gigi pendidik dituntut untuk menyampaikan pembelajaran mengenai kesehatan terutama 
kesehatan gigi dan mulut salah satu caranya dengan menggosok gigi, namun sering kita jumpai anak yang kurang tertarik dalam belajar sehingga pembelajaran terasa membosankan. Untuk menghindari keadaan tersebut peran pendidik harus kreatif dalam menyampaikan pembelajaran harus memilih dan mengorganisasikan pembelajaran tersebut sedemikian rupa bisa juga menggunakn berbagai media pembelajaran, sehingga merangsang dan menantang siswa atau mahasiswa untuk mempelajarinya.

Pengertian media pembelajaran. Secara harfiah media merupakan perantara atau pengantar. Kustandi (2011) mengemukakan bahwa "media adalah perantara atau pengantar pesan dari pengirim ke penerima pesan". Sedangkan menurut Raharjo (dalam Kustandi dan Sutjipto, 2011, hlm. 7) mengemukakan bahwa "media adalah wadah dari pesan yang oleh sumbernya diteruskan kepada sasaran atau penerima pesan yang oleh sumbernya ingin diteruskan kepada sasaran atau penerima pesan tersebut". Dalam hal ini materi yang diterima adalah pesan intruksional, sedangkan tujuan yang ingin dicapai adalah tercapainya proses belajar.

Pembelajaran adalah suatu kegiatan yang bertujuan. Tujuan ini harus searah dengan tujuan belajar siswa dan kurikulum. Tujuan belajar siswa adalah tercapainya aspek-aspek perkembangan yang optimal. Pembelajaran anak usia dini adalah proses interaksi antara pendidik dan peserta didik melalui kegiatan bermain pada lingkungan belajar yang aman dan menyenangkan dengan menggunakan berbagi sumber belajar (Kemenag 2016:4).

Jadi media pembelajaran adalah sarana untuk meningkatkan kegiatan proses belajar mengajar. Oleh sebab itu peneliti mengangkat media HDB (Healty Dental Box) sebagai media pembelajaran yang akan diteliti dan diuji cobakan.

Media pembelajaran digunakan sebagai sarana pembelajaran di Sekolah bertujuan untuk meningkatkan mutu pendidikan. Masykur (2017 hlm 179) mengungkapkan "Media pembelajaran dapat digunakan sebagai perantara yang berguna untuk meningkatkan efektifitas dan efisiensi dalam mencapai tujuan". Adapun fungsi dari penggunaan media pembelajaran menurut Levied an Lentz (dalam Kustandi dan Sutjipto, 2011, hlm. 21-22) mengemukakan fungsi media pembelajaran khususnya media visual, yaitu:

a. Fungsi Atensi, yaitu: menarik dan mengarahkan perhatian siswa untuk berkonsentrasi kepada isi pelajaran yang berkaitan dengan makna visual yang ditampilkan

b. Fungsi Afektif, yaitu: media visual dapat terlihat dari tingkat kenikmatan siswa ketika belajar

c. Fungsi Kognitif, yaitu: media visual terlihat dari teuan-temuan penelitian yang mengungkapkan bahwa lambing visual atau gambar memperlancar pencapaian tujuan untuk memahami dan mengingat informasi atau pesan yang terkandung didalamnya

d. Fungsi Kompensatoris, yaitu: media pembelajaran terlihat dari hasil penelitian bahwa media visual yang memberikan konteks untuk membantu siswa memahami teks.

Jadi dapat ditarik kesimpulan fungsi media pembelajaran dapat membantu mempermudah proses belajar dan pembelajaran bagi siswa dan pendidik, memberikan pengalaman yang lebih konkret, menarik perhatian, menarik minat siswa, dan dapat menyelaraskan antara teori dan realita.

Media Healthy Dental Box (HDB) merupakan media yang dikembangkan dalam penelitian ini media ini dapat diartikan sebagai alat bantu pembelajaran agar anak mampu dan terampil dalam menggosok gigi. Peneliti memberi nama media tersebut HDB yang tidak lain singkatan dari Healthy Dental Box. Media ini berbentuk box yang terdapat dua bagian mulut ada mulut dengan keadaan gigi bersih dan bagian satunya lagi gigi yang kotor. Cara bermainnya cukup sederhana namun perlu kejujuran anak ketika menentukan berapa kali ia menggosok gigi dalam satu hari. HDB (Healthy Dental Box) diharapkan anak mampu 
dan terampil dalam menggosok gigi. Media ini juga diharapkan dapat mengembangkan berbagai aspek perkembangan diantaranya fisik motorik, selain fisik motorik media ini juga diharapkan dapat meningkatkan berbagai aspek perkembangan lainnya. Media HDB (Healthy Dental Box) adalah suatu media yang digunakan dengan cara bermain memasukan bola berangka yang menunjukan angka berapa kali anak menggosok gigi dalam sehari, bola tersebut dimasukan kedalam lubang yang nantinya akan keluar pada mulut yang bersih sehat atau kotor dan berbau sesuai dengan angka berapa kali anak menggosok gigi dalam sehari. Media HDB (Healthy Dental Box) merupakan media visual yang efektif untuk menyampaikan atau menyajikan pesan-pesan tertentu pada sasaran tertentu pula. Bola-bola yang digunakan bisa digunakan kembali sehingga media ini dapat dipakai berkali-kali serta dapat dipakai pula untuk mengenalkan pada anak pentingnya menggosok gigi. Karena dalam media ini misalkan anak menggosok gigi sekali saja dalam sehari maka bola otomatis akan keluar pada mulut yang terdapat gigi kotor, berlubang, berbau dan terdapat kuman-kuman yang berbentuk gambar mengerikan sehingga nantinya mempermudah proses penyampaian materi.

Penggunaan Media HDB (Healthy Dental Box) dalam Pembelajaran Menggosok Gigi menggunakan beberapa tahap yaitu tahap persiapan, pelaksanaan, dan tindak lanjut.

1. Tahap persiapan

Tahap persiapan merupakan kegiatan awal dan persiapan secara teknis dalam menggunakan media HDB (Healthy Dental Box). Sebelum menggunaan Media HDB (Healthy Dental Box) dalam pembelajaran, guru hendaknya melakukan hal-hal berikut:
a. Menyusun jadwal yang disesuaikan dengan
b. topik dan program belajar yang sudah dibuat.
c. Memeriksa kelengkapan peralatan termasuk Media Healthy Dental Box (HDB)

2. Tahap Pelaksanaan
Dalam tahapan pelaksanaan permainan dilakukan dengan cara berkelompok. Hal yang pertama dilakukan

a. Guru mengatur tempat duduk sesuai dengan kelompoknya masing-masing

b. Guru memberikan arahan mengenai penggunaan media Healthy Dental Box (HDB) dan cara bermainnya.

c. Setelah itu guru memberikan kesempatan kepada tiap kelompok untuk mencoba memainkan media HDB (Healthy Dental Box)

d. Ketika berlangsungnya anak menggunakan HDB (Healthy Dental Box) guru mengawasi dan membimbing jalannya permainan tersebut serta menjelaskannya.

e. Setelah semuanya mencoba guru mengarahkan anak untuk praktek menggosok gigi di wastafel sekolah dengan setting tempat yang sudah disiapkan.

f. Anak mengambil sikat gigi, pasta gigi dan gelas masing-masing.

g. Atur posisi anak sehingga mudah untuk menyikat gigi

h. Setelah anak-anak berjejer rapi selanjutnya melakukan gosok gigi bersama dengan didampingi guru

i. Setelah melakukan kegiatan menggosok gigi lalu masuk kelas selanjutnya guru menjelaskan kembali fungsi menggosok gigi dan manfaatnya.

3. Tahap Tindak Lanjut

Pada tahap ini guru melakukan hal sebagai berikut:

a. Memberikan arahan atau informasi tentang pentingnya menggosok gigi.

b. Memberikan pertanyaan atau umpan balik kepada siswa.

Media Healthy Dental Box bisa disebut dengan media tiga dimensi dan juga media model. Menurut Daryanto (2013:29) kelebihan media tiga dimensi adalah "memberikan pengalaman secara langsung, penyajian konkrit dan menghindari verbalisme, menunjukan objek secara utuh memperlihatkan struktur dan alur secara jelas". Kelemahan media model adalah sulit menjangkau sasaran dalam jumlah 
besar. Media HDB memiliki kelebihan dan kekurangan dalam memberikan pembelajaran menggosok gigi. Berikut kelebihan dan kekurangan media HDB untuk meningkatkan keterampilan menggosok gigi pada anak usia 4-5 tahun:

1. Kelebihan media media HDB (Healthy Dental Box) yaitu dapat membantu anak meningkatkan keterampilan menggosok gigi, memperlihatkan gigi yang tidak sehat dan gigi yang sehat, menimbulkan minat siswa karena media memiliki bentuk yang unik juga disajikan sebagai permainan, membantu memperjelas cara menggosok gigi yang baik dan benar dan membantu menjelaskan betapa pentingnya menggosok gigi.

2. Kekurangan Media HDB (Healthy Dental Box) yaitu media inicukup berat dan memerlukan biaya yeng cukup besar untuk membuat media ini.

Penelitian menggunakan media HDB (Healthy Dental Box) atau media tiruan sejenisnya juga pernah dilakukan oleh mahasiswa lain, diantaranya:

Penelitian yang dilakukan oleh Westy August Nurhawati, Sri Hartini M.A, M.Kep., Sp.Kep.An dan Eko Purnomo, SKp., M.Kep dengan judul "Pengaruh Bercerita Menggunakan Media Boneka Gigi Terhadap Peningkatan Perilaku Cara Menggosok Gigi dengan Benar pada Anak Usia 4-5 Tahun di TK Pertiwi 07 Mijen Semarang". Berdasarkan penelitian tersebut bahwa pengaruh peningkatan perilaku menggosok gigi antara sebelum dan sesudah diberi cerita menggunakan media boneka gigi berbeda secara bermakna. Nilai korelasi Spearmen sebesar 0,786 menunjukan korelasi dengan kekuatan korelasi kuat.

Penelitian yang dilakukan oleh Fachruniza Privita Hidayati dengan judul "Peningkatan Kemampuan Menggosok Gigi Melalui Media Boneka Gigi pada Anak Tunagrahita Kategori Sedang Kelas IV di SLB-C Rindang Kasih Secang". Berdasarkan penelitian tersebut terjadi peningkatan dari post- test atau pasca tindakan dan sesudah tindakan dengan subjek tiga orang siswa yaitu; ARH, EPD dan ILP mengalami peningkatan skor hasil observasi proses pembelajaran pada guru menggunakan media boneka gigi yaitu dengan skor peningkatan pada ARH dari Siklus I ke siklus II terdapat peningkatan presentase $15 \%$, EDP 7,5\% dan ILP 21,5\%.

Produk yang diharapkan dari penelitian dan pengembangan ini adalah dapat memfasilitasi keterampilan menggosok gigi anak usia 4-5 tahun. Media ini diharapkan menjadi solusi dalam menyelesaikan permasalahan yang berkaitan dengan keterampilan menggosok gigi anak. produk ini dibuat dengan semenarik mungkin agar memberikan motivasi kepada anak untuk mengikuti pembelajaran dan memberikan kemudahan guru dalam mengajarkannya.

Desain produk dari media Healthy Dental Box (HDB) ini dikemas dalam bentuk kubus yang dilengkapi dua bagian mulut yang bersih dan kotor untuk memudahkan anak membedakannya dibagian gigi kotor bagian gigi tidak sempurna ada bagian gigi yang terkena karies, karang gigi dll berbeda pada gigi bersih susunan gigi dibuat rapih dan bersih tanpa noda sedikitpun. Pada bagian atas box terdapat satu lubang dan dua tombol untuk mengatur jalannya bola yang dimasukan sesuai dengan kebiasaan berapa kali anak menggosok gigi.

HR. Bukhari (dalam Erwana, F.A, 2014. Hlm 43) "Andaikan tidak memberatkan umatku, niscaya kuperintahkan mereka untuk gosok gigi setiap hendak sholat". Menggosok gigi merupakan suatu aktivitas yang terdapat dalam program pengembangan diri. Bersiwak bisa membersihkan mulut dan mendatangkan ridha Allah. (HR Nasa'I dan disahihkan alAlbani). Mumpuni, Y. \& Pratiwi, E. (2013) menyatakan bahwa "Gigi merupakan tulang keras dan kecil-kecil berwarna putih yang tumbuh tersusun, berakar dalam gusi dan berfungsi untuk mengunyah juga menggigit".

Menggosok gigi sangat penting untuk dikembangkan secara maksimal agar anak dapat mencapai tugas perkembangan motoriknya secara optimal. Pelatihan 
menggosok gigi bagi anak perlu dipelajari bagian demi bagian dengan perlahan. Menyikat gigi pada anak dapat mengembangkan perkembangan motorik dari cara memegang sikat gigi, memegang gayung, mengambil air dari bak, menuangkan pasta gigi ke atas sikat gigi, berkumur, menyikat gigi dari bagian depan, kiri, kanan, atas, bawah, berkumur membersihkan busa, membersihkan peralatan gigi, dan mengembalikannya ketempat semula.

Jadi penting meningkatkan keterampilan menggosok gigi pada anak sejak dini karena pada dasarnya setiap anak mempunyai potensi untuk menyalurkan kebutuhan. Kemampuan menggosok gigi anak bisa dilatih melalui permainan boneka gigi/ HDB.

Adapun yang menjadi anggapan dasar pada penelitian ini adalah :

1. Anak belajar melalui kegiatan yang konkret

2. Dunia anak adalah dunia bermain, sehingga anak akan antusias dalam kegiatan yang menyenangkan

3. Kemampuan menggosok gigi untuk mengembangkan aspek perkembangan anak

Pembelajaran yang optimal adalah pembelajaran yang berjalan dengan terpenuhinya komponen pembelajaran. Komponen pembelajaran terdiri dari guru, siswa, tujuan, prosedur belajar mengajar, evaluasi dan media pembelajaran. Keenam komponen tersebut saling berkaitan jika terjadi sinergi yang baik maka pembelajaran akan berjalan secara optimal dan siswa dapat menyerap seluruh materi pelajaran dengan baik.

Dari komponen pembelajaran yang menjadi pusat pembelajaran yaitu guru. Guru dituntut untuk bisa menyampaikan materi pembelajaran kepada siswa-siswinya, untuk lebih mempermudah penyampaian materi tersebut pendidik tentunya memerlukan media pembelajaran yang sesuai dengan tema yang akan disampaikan disetiap harinya. Agar anak mampu menyerap pembelajaran dengan baik, karena pada dasarnya anak usia dini berpikir konkreat yan tentunya setiap pembelajaran tema yang disampaikan memerlukan benda nyata atau model yang disesuaikan untuk anak, agar proses pembelajaran berlangsung lancar dan anak terlibat langsung pada proses pembelajaran tersebut.

Media pembelajaran yang digunakan haruslah menarik sehingga anak lebih tertarik untuk belajar. Media pembelajaran juga harus membuat anak lebih penasaran dan memberikan efek yang membuat anak ingin terlibat langsung pada proses pembelajaran sehingga setelah pembelajaran selesai memberikan pengalaman yang bermakna bagi anak.

Media Healty Dental Box atau HDB merupakan sebuah inovasi dalam lingkup pengembangan media pembelajaran, dalam dunia kesehatan yang ditarik ke dalam dunia pendidikan untuk mengedukasi peserta didik, yang akan muncul di benak anak adalah kesan terhadap media pembelajaran ini. Ketika anak ikut menggunakan media pembelajarannya di bawah bimbingan guru, maka pembelajaran akan lebih menarik dan efektif.

Penelitian ini dilakukan untuk mengembangkan dan menghasilkan media pembelajaran berupa Healty Dental Box $(H D B)$ dalam pembelajaran motorik anak usia dini khususnya dalam kesehatan dan perilaku keselamatan pada anak usia 4-5 tahun.

Dengan adanya media pembelajaran ini, diharapkan dapat menciptakan pembelajaran yang menyenangkan dan memberikan pengalaman belajar yang berarti bagi anak dalam mencapai tujuan dari pembelajaran.

\section{METODE}

Metode penelitian yang digunakan dalam penelitian ini adalah Design Based Research (DBR). Richey (Emzir, 2015: 264) mendefinisikan penelitian desain dan pengembangan sebagai "The systematic study of design, development and evaluation processes with the aim of establishing an empirical basis for the creation of instructional and noninstructional product and tools and new or enhanced models that govern their development". Suatu studi sistematis tentang proses desain, pengembangan, dan evaluasi 
yang bertujuan membangun dasar empiris untuk menciptakan produk instruksional dan nonintruksional serta alat-alat dan model baru atau model yang ditingkatkan dengan pengembangannya.

Lidinillah (2012) mengungkapkan design based research adalah "suatu kajian sistematis tentang merancang, mengembangkan dan mengevaluasi intervensi pendidikan (seperti program, strategi dan bahan pembelajaran, produk dan sistem) sebagai solusi untuk memecahkan masalah yang kompleks dalam praktik pendidikan, yang juga bertujuan untuk memajukan pengetahuan kita tentang karakteristik dari intervensi-intervensi tersebut serta proses perancangan dan pengembangannya".

Berdasarkan dari pembahasan ahli diatas peneliti menggunakan metode pengembangan Design Based Research (DBR) karena sesuai dengan tujuan dari peneliti yaitu merancang, mengembangkan, dan menguji kelayakan dari produk yang dibuat untuk mengatasi masalah dalam pembelajaran. Peneliti akan mengembangkan media pembelajaran Healty Dental Box (HDB) yang berbentuk box dengan dilengkapi dua bagian gigi yang bersih sehat dan gigi yang kotor atau tidak sehat untuk memfasilitasi keterampilan menggosok gigi pada anak usia 4-5 tahun yang sedang duduk di kelompok A. Oleh karena itu metode DBR cocok diterapkan pada penelitian ini.

\section{HASIL DAN PEMBAHASAN}

Berdasarkan data observasi, dokumentasi, wawancara dan validasi media menunjukan Media Healthy Dental Box (HDB) layak digunakan di lapangan. Penggunaan media ini diadopsi dari media boneka gigi dan dikembangkan menjadi media Healthy Dental Box (HDB).

Penelitian ini sampai ke validasi ahli karena penelitian ini terhambaterhambat dengan adanya virus corona atau covid'19 yang mewabah dibelahan dunia sehingga sekolah diliburkan, jadi penelitikesulitan untuk melanjutkan penelitian. Sehingga penelitian ini sampai ke validasi ahli. Berdasarkan hasil validasi beberapa ahli diantaranya ahli kesehatan, ahli media pembelajaran dan ahli pedagogic menyatakan media ini layak untuk selanjutnya digunakan di lapangan.

Menggosok gigi yang baik dan benar menjadikan gigi sehat. Namun jika menggosok gigi belum tepat maka mengakibatkan gigi tidak sehat. Gigi yang tidak sehat menyebabkan bau mulut akan mengganggu dalam berkomunikasi. Oleh sebab itu, penting bagi anak untuk merawat gigi sejak dini dengan menggosok gigi agar gigi tetap sehat dan mulut tidak sehat dan tidak berbau. Namun faktanya masih ada anak usia dini dalam menggosok gigi hanya menyikat bagian tertentu saja tidak mengikuti tahapan dengan benar. Sehingga hasil yang didapat sering kali kurang bersih dan menimbulkan penyakit gigi.

Menurut hasil observasi dan wawancara, pada kenyataanya di salah satu TK di Kota Tasikmalaya sebagian besar anak disana masih rendah kesadarannya terhadap kebersihan gigi, bahkan anak-anak sulit sekali menggosok gigi. Anak-anak juga masih kurang terampil dalam menggunakan jari-jari tangan untuk melakukan kegiatan menggosok gigi.

Penelitian mengenai media Healthy Dental Box (HDB) untuk memfasilitasi keterampilan menggosok gigi anak usia 4-5 tahun menggunakan pendekatan kualitatif dan kuantitatif dengan metode Design Based Research (DBR) menurut Amiel dan Reeves (2008) prosedur penelitian Design Based Research (DBR), sebagai berikut sesuai fakta di lapangan:

1. Analysis of practical problems by researches and practitioners in collaboration

Masalah yang tampak pada saat melakukan studi pendahuluan salah satu Tk di Cipedes yaitu sebagian besar anak masih rendah kesadarannya terhadap kebersihan gigi, bahkan anak-anak sulit sekali menggosok gigi. Anak-anak juga masih kurang terampil dalam menggunakan jari-jari tangan untuk melakukan kegiatan menggosok gigi. Media yang tersedia di sekolah tersebut juga masih terbatas hanya ada media gambar atau poster yang digunakan pada proses pembelajaran mengenai 
menggosok gigi. Maka dari itu dalam penelitian ini peneliti menggunakan media sebagai alat bantu anak agar mampu dan terampil dalam menggosok gigi. Peneliti memberi nama media tersebut Healthy Dental Box (HDB).

2. Development of solutions informed by existing design principles and technological innovations

Produk yang dibuat berupa media pembelajaran Healthy Dental Box (HDB) untuk memfasilitasi keterampilan menggosok gigi anak usia 4-5 tahun. Media Healthy Dental Box ini tercipta setelah peneliti menemukan masalah di lapangan pada saat melakukan studi pendahuluan. Desain produk media pembelajaran ini dikemas dengan bentuk semenarik mungkin terbuat dari kain flanel yang diisi dakron layaknya sebuah boneka namun media ini ditambahkan box yang terbuat dari kayu sehingga media ini kuat dan tahan lama. Media ini memiliki bentuk seperti box yang memiliki dua bagian mulut, mulut yang satu memiliki kondisi yang bersih sehat mulut yang lainnya memiliki kondisi yang kotor Healthy Dental Box ini difasilitasi dengan replika pasta gigi dan sikat gigi dengan bentuk yang menarik dan juga memiliki bola dengan difasilitasi angka untuk menentukan berapa kali anak tersebut menggosok gigi. Media Healthy Dental Box (HDB) ini digunakan pada tema diriku dan sub tema anggota tubuh serta media pembelajaran ini mudah untuk digunakan dan juga praktis.

3. Iterative cycles of testing and refinement of solutions in practice

Untuk memperoleh kelayakan produk peneliti melakukan uji validasi kepada ahli dibidang kesehatan, ahli media pembelajaran dan ahli pedagogik. Kritik dan saran validator menjadi dijadikan sebagai bahan revisi sehingga media ini memiliki kelayakan yang baik untuk digunakan dilapangan. Dari ketiga validator dihasilkan bahwa media ini layak digunakan di lapangan dengan beberapa perbaikan diantaranya melengkapi media dengan manual book dan menambahkan roda pada media tersebut.
4. Reflection to produce "design principles" and enhance solution implementation

Peneliti melakukan refleksi untuk menghasilkan produk akhir dari media pembelajaran ini yaitu media Healthy Dental Box Box (HDB) yang telah dilengkapi manual book sebagai buku pegangan pendidik atau pengguna lainnya.

\section{KESIMPULAN}

Berdasarkan hasil penelitian yang telah dilakukan mengenai pengembangan media Healthy Dental Box (HDB) untuk memfasilitasi keterampilan menggosok gigi anak usia 4-5 tahun, didapatkan kesimpulan sebagai berikut:

Berdasarkan analisis pada studi pendahuluan yang telah dilakukan oleh peneliti, didapatkan bahwa penggunaan media pembelajaran di sekolah digunakan apabila dibutuhkan karena penggunaannya disesuaikan dengan tema yang sedang berlangsung. Media pembelajaran untuk memfasilitasi keterampilan menggosok gigi sebelumnya masih menggunakan gambar (poster) dan papan tulis saja. Sehingga minat belajar anak kurang antusias dan hasil belajar anak kurang optimal.

Pengembangan media Healthy Dental Box (HDB) untuk memfasilitasi keterampilan menggosok gigi anak usia 4-5 tahun dibuat berdasarkan permasalahan yang ditemui saat melakukan studi pendahuluan terkait masalah yang ada di salahsatu TK di Cipedes. Didukung dengan studi literatur yang merupakan bagian dari pemecahan masalah agar mendapatkan solusi yang diharapkan. Kemudian peneliti melakukan pengembangan produk dengan menganalisis kurikulum, kemudian menyusun storyboard. Pada tahap selanjutnya adalah validasi terhadap produk yang telah dibuat peneliti dengan melibatkan validator ahli sesuai dengan bidang keahlian masing-masing, yaitu validator ahli bidang kesehatan, ahli media pembelajaran, dan ahli pedagogik. Produk divalidasi oleh validator ahli dengan melampirkan lembar validasi dan memperlihatkan media yang dibuat peneliti. 
Dengan berbagai perbaikan sehingga media ini layak untuk digunakan di lapangan.

\section{SARAN}

Berdasarkan temuan dan pembahasan yang diperoleh dari penelitian ini, maka didapatkan beberapa rekomendasi dari peneliti yang dipaparkan sebagai berikut:

a. Bagi pengguna media Healthy Dental Box (HDB) diharapkan dapat menggunakan semua komponen media secara optimal dan mengemasnya dengan pembelajaran yang menarik, seperti dikemas dengan permainan serta hal lainnya yang dapat membangkitkan motivasi belajar anak.

b. Media pembelajaran yang peneliti buat masih jauh dari kata sempurna. Oleh sebab itu pengembangan media yang telah dibuat peneliti dapat dikembangkan kembali oleh mahasiswa, guru dan juga pihak lainnya agar produk ini menjadi lebih baik lagi dari sebelumnya.

c. Pengembangan yang dihasilkan berupa media pembelajaran dalam bentuk permainan edukatif. Permainan yang dihasilkan melalui penelitian ini dapat dijadikan sebagai media pembelajaran untuk memfasilitasi keterampilan menggosok gigi anak usia 4-5 tahun.

\section{DAFTAR PUSTAKA}

Baruah, K. dkk (2017). A Review on Toothbrushes and Tooth Brushing Methods. Internasional Jurnal of Pharmaceutical Science Invention Volume IV issue 51. 29-38.

Chomaria, N. (2015). Panduan Terlengkap Tumbuh Kembang anak Usia 0-5 Tahun. Surakarta: Cinta Menebar Cinta Menuah Hikmah.

Daryanto. (2013). Media Pembelajaran. Yogyakarta:Gava Media.

Erwana, F.A. (2014). Mitos dan Fakta Tumbuh Kembang Gigi Anak. Yogyakarta: Rapha Publishing.

Erwana, F.E. (2013). Seputar Kesehatan Gigi dan Mulut. Yogyakarta: Rapha Publishing.

Giri, K.D. (2018). Effectiveness Between Two Tooth brushing Methods on Removing Dental Plaque. Jurnal Nobel Medical College. Vol 7(1). Edisi 12. Hlm 26-29.
Hidayat, R. (2016). Kesehatan Gigi dan MulutApa yang Sebaiknya Anda Tahu. Yogyakarta: CV Andi Offset.

Hidayati,P, F. (2016). Peningkatan Kemampuan Menggosok Gigi Melalui Media Boneka Gigi pada Anak Tunagrahita Kategori Sedang Kelas IV di SLB-C Rindang Kasih Secang. Universitas Negeri Yogyakarta. SKRIPSI

Izzeti. R. dkk. (2020). COVID-19 Transmission in Dental Practice: Brif Review of Preventive Measures in Italy. Journal of Dental Reaserch. 1-2.

Kemendikbud, R. I. (2014). Permendikbud Nomor 137 Tahun 2014 Tentang Standar Pendidikan Anak Usia Dini.

Kustandi, C. \& Sutjipto, B. (2011). Media Pembelajaran Manual dan Digital. Bogor: Ghalia Indonesia

Lakshmi, V. dkk (2018). Evaluation of Brushing Techniques and Toothbrush Grips Among Rural and Urban Children. International Jurnal of Applied Dental Sciences. VI (II). 164-167.

Lokhandwala, H. dkk. (2020). Factor Associated with Use of Dental Sealants among Dental Professionals in Mangalore-A Cross Sectional Stusy. Indian Journal of Public Health Reaserch \& Devlopment. An International Jurnal. Vol 11. No 01. Hal 477483.

Masykur, dkk. (2017). Pengembangan Media Pembelajaran Matematika dengan Macromedia Flash. Jurnal Pendidikan Matematika. Vol 8. No.2. hal 179

Mumpuni, Y. \& Pratiwi, E. (2013) 45 Masalah dan Solusi Penyakit Gigi dan Mulut. Yogyakarta: Rapha Publishing

Nardi, M.G. dkk. (2016). Tailored Brushing Method (TBM): An Innovative Simple Protocol to Improve the Oral Care. Jurnal of Biomedicine. Vol 1.26-31.

Ngatemi \& Purnama, T. (2020). Dental Health Handbook as Parents Monitoring in the Formation of Independence 
for Brushing Teeth in Early Childhood. Indian Journal of Public Health Reaserch \& Devlopment. An International Jurnal. V11. No 01. hal. 767.

Rahardjo, A. dkk. (2014). Measurement of Tooth Brushing Frequency, Time of Day and Duration of Adults and Children in Jakarta, Indonesia. Jurnal of Dentistry Indonesia. Vol XXI (III). 85-88.

Razeghi, S. dkk. (2020). Impact of Health Promotion Interventions on Early Chilhood Caries Prevention in Children Aged 2-5 Years Receiving Dental Treatment Under General Anesthesia. University of Medical Seciences Tehran Iran.

Ryadi, S.L.A. (2018). Ilmu Kesehatan Masyarakat. Andi: Yogyakarta.

Santyasa W. (2007). Landasan Konseptual Media Pembelajaran. Banjar Angkn Klungkung.

Sujiono, Y. (2012). Konsep Dasar Pendidikan Anak Usia Dini. Jakarta: PT Indeks Permata Puri.

Undang-Undang No. 36 tahun 2009 tentang kesehatan.

World Health Organization (WHO)

Yasbiati. dkk. (2017) Strategi Pengembangan Fisik Motorik. Tasikmalaya: Universitas Pendidikan Indonesia.

Zulkifli, A. \& Putri, A.R. (2020). Aplikasi Diagnosa Penyakit Gigi dan Mulut Menggunakan Metode Forward Chaining. Jurnal of Computer Science. Volume VI (1). 71-80. 